\title{
Importance of Interdisciplinary Spatial Planning of National Parks: Case Study of Croatia
}

\author{
Izidora Marković \\ Institute for Tourism, Zagreb, Croatia \\ Iva Babić \\ OŠ Jelkovec, Zagreb, Croatia
}

\begin{abstract}
With the attempt to "reconcile" protection and tourism activities, spatial planning has a great importance in sustainable planning and management of Nature Protected Areas (NPAs). The spatial dimension of sustainability involves numerous processes and links among different purposes of lands, ecosystems, and biotopes at different levels through time, therefore, it is necessary to include all sciences and professions, whose common goal is the sustainability of the area, in the spatial planning process. This paper argues that there is a critical need for an interdisciplinary approach in spatial planning, which could improve the quality of planning of national parks and all other sensitive nature areas. Such approach should strive to the sustainability of protected nature destinations with the integration of knowledge. In Croatia, national park planning is still mostly done without comprehensive and integrated involvement of a wide range of science and profession, which ultimately significantly reduces the quality of the plans, as well as may have potentially negative effects on the future development.
\end{abstract}

Keywords: spatial planning, national parks, protected area, interdisciplinary

Preserved space is a unique resource which is impossible to reproduce. This is the reason why more and more valuable nature areas worldwide are mostly protected because of their uniqueness, but in some cases, they are protected because of their vulnerability. Consequently, tourism environment and communities are in continuous feedback, which by its nature is positive in early and less intense stages, but leads to negative feedback with the increase in tourist activity (Martinić, 2010). The scenery as a background is the main tourist attraction in Croatia and over $20 \%$ of all tourist arrivals in Croatia are motivated primarily by exploring Nature Protected Areas (NPAs), especially national and nature parks (Institute for Tourism, 2006). Furthermore, there is constant increase in the number of visitors to NPAs, which represents a burden for the sensitive resources of the areas. Tourism in nature protected areas is based on maximizing profit regardless of the sustainability, which is proved by lack of operational management plans, by lack of determined carrying capacity, etc. National parks represent current generators of development in the areas as they are the most frequently visited

Corresponding author: Izidora Marković, mag. Geo. \& Geol., junior researcher, Institute for Tourism, Zagreb, Croatia; research fields: sustainability, protected areas, management, planning, impacts and identity of community. E-mail: izidora.markovic@iztzg.hr.

Iva Babić, mag. Geo. \& Geol., lecturer, OŠ Jelkovec, Zagreb, Croatia; research fields: geography education, geomorphology, karst, and hydrology. E-mail: ivababic28@yahoo.com. 
protected areas. Also, they are larger by extent and therefore represent some of the most intensely used natural tourist areas. Because of that, it is extremely important to plan these areas in such a manner that all the activities the National Park (NP) includes, such as: Protection, education, research, recreation and tourism, have an appropriate base in spatial planning and management plans that derive from it. Therefore, the main objective of this paper is focused on the identification and involvement of all components of the area in spatial planning, in terms of involvement of experts from a range of professions and sciences.

Large number of papers are dedicated to the topic of spatial planning of urban centers and regions with emphasis on urban planning (Pueyo-Anchuela, Casas-Sainz, Pocoví Juan, \& Ansón-López, 2011), while little attention is given to the spatial planning of rural areas. There is no doubt that spatial planning has evolved from urban planning, but due to the complexity of the problems in space, the role of interdisciplinarity is extremely important (Marinović-Uzelac, 2001). Interdisciplinarity in the case of spatial planning can be considered as a functional cooperation between different fields and sciences, engaged in a unique task, where it is extremely important to reconcile their specific knowledge in order to create a spatial plan (see Figure 1). It is important to point out that interdisciplinary approach cannot be identified with the multidisciplinary approach, since it significantly distinguishes interests in certain fields, which is not in compliance with the achievement of a common goal in the planning area.



Figure 1. Formation and organization of spatial planning professional team. Source: authors, adapted by Marinović-Uzelac, 2001.

Several different activities in the preparation of spatial plans can usually be pointed out and, along with that, different specialists for each activity (Marinović-Uzelac, 2001):

(1) Specialists for "activities": demographers, economists, tourism experts, industry experts, and others;

(2) Specialists for "space": architects, landscape architects, agronomists, geographers, geologists, pedologists, geodesy experts, and others;

(3) Specialists for "communications": transport engineers, telecommunications experts, public transport experts, and marketing experts; 
(4) Specialists for "general service": sociologists, politics experts, analysts, economists, public administration experts, management experts, and others;

And in cases of protected nature areas,

(5) Specialists for "protection": biologists, ecologists, ethnologists, sustainable tourism experts, hydrologists, geologists, geographers, and others.

Because of the complexity of protected nature area planning and due to the development of the Geographic Information System (GIS) software, it is highly important to include specialist in GIS in the planning team, to support sustainable spatial planning and resource management (Brown \& Weber, 2011; Haslauer, Biberacher, \& Blasche, 2012).

Since protected natural areas, including national parks, are parts of the rural area due to their specifics and sensitivity of the area, they must be planned as an integrated whole with many constituents. Therefore, it is extremely important that participation of researchers of all professions is assured, which can affect the sustainability of development of the area. The Croatian national parks, with all their ecological, geological, and landscape values, have an extremely important role in the development. This is highly important especially in planning areas which are encompassing few administrative units, where spatial plans have to be coordinated in the function of area protection (Berke, Spurlock, \& Band, 2013). With the attempt to "reconcile" protection and tourism activities, interdisciplinary planning can have a great importance in sustainable planning and management of NPAs (Fagence, 1990). The inclusion of permanent teams, primarily planning departments, as well as the involvement of external experts with extensive experience in the planning of national parks is essential in the formation of such complex plans, such as spatial planning of national parks.

In order for a planner to take part in the process of spatial planning, it is necessary for him to (McLaughin, 1969):

(1) Understand the nature and behavior of the system (context of planning);

(2) Differ elements of the system and subsystems, as well as the way in which other experts of spatial planning approach the problem (management and integration of operations);

(3) Cooperate in defining the goals set for the system (recognize the imperatives of spatial development);

(4) Find the most appropriate methods for the system (knowledge of modern methods);

(5) Bear responsibility for system planning (understand the role of) spatial planner.

Planning for protected area networks is often done on an ad hoc basis (Johnson, Kanderiana, Shanka, Rahmani, \& Lawsona, 2012). When it comes to plans of protected areas, they are not frequently implemented. Even after considerable time and money are invested in applied research, analysis and planning, many plans simply wind up "on the shelf" (Plasman, 2008), having as one of the obstacles lack of politicians in the planning team, which would allow better understanding of the propositions to the public and the administration (Liu, Wu, Jhan, \& Ho, 2011). Recognizing the differences between scientists and policy-makers is the first step toward making better use of science in policy-making and the improvement of the chances for implementation. Improving the interactions between scientists and policy makers needs to receive continued attention. Interdisciplinary team can have several independent approaches which give results that can only be clearly interpreted when integrated as a whole.

Protected area zoning is a decision-making issue that inherently requires the evaluation of multiple land attributes according to multiple objectives. To promote transparency and facilitate communication with stakeholders, a clear step-by-step methodology needs to be adopted (Geneletti \& Duren, 2008). Diversification 
of society, pressures and complexity of planning issues, requires communicative planning (Elliot \& Udovč, 2005; Hu, Roo, \& Lu, 2013), which can be more easily achieved through specialists in social sciences.

\section{Croatia's National Parks}

Croatia belongs to European countries with high percentage of land and sea under various forms of protection and with large number of various protected natural areas. According to the Nature Protection Act of 2012, there are 433 protected areas covering 682,451 hectares or $12.1 \%$ of total land and 60,339 hectares or $1.9 \%$ of Croatian territorial sea area (Narodne Novine, 2013). There are nine types of protected natural areas: national parks, nature parks, strict nature reserves, special nature reserves, regional parks, important landscapes, nature monuments, forest parks, and park architecture monuments (see Table 1). The most important and valuable are eight national parks and 11 nature parks, covering the majority of protected areas. They are proclaimed by acts of the Croatian Parliament and managed by public institutions founded by the national government.

Table 1

Types of Protected Areas in Croatia and Their Land and Sea Area

\begin{tabular}{lccc}
\hline Type of protection & Number of protected areas & Land area in hectares & Sea area in hectares \\
\hline National park & 8 & 73,567 & 21,906 \\
Nature park & 11 & 401,755 & 17,867 \\
Strict nature reserve & 2 & 2,395 & 0 \\
Special nature reserve & 80 & 32,095 & 12,007 \\
Regional park & 2 & 102,792 & 0 \\
Important landscape & 85 & 123,306 & 8,988 \\
Nature monument & 85 & 3,270 & 0 \\
Forest park & 33 & & 0 \\
\hline
\end{tabular}

National, nature, and regional parks cover larger areas, usually over 10,000 square kilometers and include various elements of nature under protection. They differ mainly regarding the level of protection, with national parks having the highest and regional parks having the lowest level of protection. Other protected areas are usually smaller and in most cases dedicated to one element of nature under protection, especially nature and park architecture monuments as the smallest protected area usually under 10 hectares. Internationally, the most important natural heritage is recorded by United Nations Educational, Scientific and Cultural Organization (UNESCO), with a total of nine natural areas under various forms of protection. The most popular Croatian national park, Plitvice Lakes, is designated as a natural world heritage site and two other protected areas-Nature Park Velebit and Regional Park Mura-Drava, as UNESCO World biosphere reserves.

High level of preservation and abundance of different and attractive landscapes resulted in big importance of natural beauties in Croatian tourism, visible through large number of visitors in attractive natural areas. The most popular natural areas from the visitors' point of view are Plitvice Lakes National Park, with more than one million visitors per year and Krka National Park, with nearly 700,000 visitors. They are exceptionally popular because they represent unique karst phenomena with many waterfalls surrounded by attractive forested landscape. Other national parks have a smaller number of visitors - between 100,000 and 200,000 visitors per year were in Brijuni and Paklenica National Park, slightly under 100,000 visitors in Kornati and Mljet national park and in the remaining two national parks, Risnjak and Northern Velebit, less than 20,000 visitors. As far as 
Brijuni is concerned, the main reason for visitation is the exceptional beauty of the islands, known as a holiday resort of statesmen and celebrities, whereas Paklenica boasts two attractive canyons and the fact that it is one of the top climbing spots in Europe easily accessible also in the winter period. Kornati are famous as a labyrinth of many uninhabited islands and the national park in the western part of the island of Mljet is a picturesque natural area with deep indented bays and preserved Mediterranean forest.

The case of two mountain national parks, Risnjak and Northern Velebit, both very important regarding preservation of nature and abundance of various and endemic wildlife species, shows that the national park status is not a sufficient factor for attracting visitors if there are no exceptional natural attractions. That is especially the case with Risnjak, whose national park status is mainly based on various and rich wildlife on the crossroads among Mediterranean, Panonian, Alpine, and Dinaric bio-geographical regions. In the case of more attractive mountain area of Northern Velebit, with very attractive trails and rocks, an important factor for relatively small number of visits is the remote location and difficult access.

\section{Spatial Planning Practice of NP in Croatia and Its Implications}

The Republic of Croatia, with its sea and coastline, forests, mountains, rivers, lakes, karst caves, and other ecosystems, is one of the most diverse countries in Europe biologically and regarding its landscape (Martinić, 2010). It is precisely a situation such as this that imposes an obligation on the entire population, especially scientists, experts and politicians, to preserve and maintain the current situation or improve the situation wherever possible. It is wrong to assume that the preserved nature is self-sufficient for future sustainability. Even man's smallest interference with it (which is inevitable in today's world) can disturb the balance of the system and impose an obligation to protect the same. The Nature Protection Act (Narodne Novine, 2013) classifies the protected areas in Croatia, according to their importance to the local area, national and international significance and according to the categories of protection, into nine categories depending on the security level, the surface of the protected areas and usage. It is particularly important to put emphasis on the method of use, which is inevitable even in protected natural areas and should therefore be properly determined.

As the first formal level of nature conservation is imposed spatial planning their determination land uses puts restrictions in accordance with which is possible to carry out the construction and use of land. In Croatia, there are several levels of spatial planning, the base of which is national, and is governed by the Physical Planning Strategy of the Republic of Croatia, the next level of regional planning for which each county must create a spatial plan for the county and local level planning by each municipality and city mandatory create a regional plan for their area. Spatial planning of protected natural areas such as national parks regulated by the regional plans special areas governing the organization of space, conditions of use, allocation, and protection of space in which to appreciate the natural, landscape, and cultural-historical value. According to the Nature Protection Act (Narodne Novine, 2008), land use plans in the Republic of Croatia (RC) are made on the basis of the professional background of the State Institute for Nature Protection, which in turn is produced in collaboration with the Directorate for Nature Protection, Ministry of Environment, and Nature Protection and Public Institution Park. Professional background is proposed zoning, based on which the park is shared by objectives (general and specific) needs protection and use and provides guidelines for planning the use of space. Each regional plan for each NP consists mainly of two parts: The textual part, which defines the objectives, general provisions, assumptions, conditions of use, organization and protection of space allocation and planning, 
infrastructure, general features and boundaries of the National Park, etc., and the graphical part which mainly consists of cartographic representations. The Ministry of Construction and Physical Planning is responsible for drawing up regional plans of national parks in Croatia and bringing them to the Croatian Parliament. From a total of eight NPs in Croatia, only Krka still has no plan in decision, but according to the information available, the plan is being drafted (see Table 2). Also, even the largest and most famous national park, Plitvice Lakes still has not got an adopted spatial plan, but the proposal of a spatial plan which is due to the many conflicts of interest for many years in the making.

Table 2

General Data of National Parks in Croatia

\begin{tabular}{|c|c|c|c|c|}
\hline Spatial plan of NP & $\begin{array}{l}\text { Year of developing } \\
\text { a spatial plan }\end{array}$ & $\begin{array}{l}\text { The area of NP } \\
(\mathrm{sq} \mathrm{km})\end{array}$ & $\begin{array}{l}\text { Registred visitors } \\
\text { in } 2012\end{array}$ & Administrative unit that includes NP \\
\hline Plitvička jezera & In decision-making & 297 & $1,157,019$ & $\begin{array}{l}\text { County: Karlovačka, Ličko-senjska } \\
\text { Municipality: Saborsko, Rakovica, } \\
\text { Vrhovine, Plitvička jezera }\end{array}$ \\
\hline Paklenica & 2001 & 96 & 114,321 & $\begin{array}{l}\text { County: Zadarska i Ličko-senjska } \\
\text { Municipality: Starigrad i Lovinac } \\
\text { County: Primorsko-goranska }\end{array}$ \\
\hline Risnjak & 2001 & 64 & 16,359 & $\begin{array}{l}\text { Municipality: Čavle, Lokve } \\
\text { City: Čabar, Delnice, Bakar }\end{array}$ \\
\hline Mljet & 2001 & 31.22 & 97,148 & $\begin{array}{l}\text { County: Dubrovačko-neretvanska } \\
\text { Municipality: Mljet }\end{array}$ \\
\hline Kornati & 2003 & 217 & 91,780 & $\begin{array}{l}\text { County: Šibensko-kninska } \\
\text { Municipality: Tisno, Murter } \\
\text { County: Istarska }\end{array}$ \\
\hline Brijuni & 2001 & 33.85 & 150,943 & $\begin{array}{l}\text { Municipality: Fažana, Vodnjan } \\
\text { City: Pula } \\
\text { County: Šibensko-kninska }\end{array}$ \\
\hline Krka & No spatial plan & 109 & 732,999 & $\begin{array}{l}\text { Municipality: Promina, Kistanje } \\
\text { City: Skradin, Knin }\end{array}$ \\
\hline Sjeverni Velebit & 2012 & 109 & 16,620 & $\begin{array}{l}\text { County: Ličko-senjska } \\
\text { City: Senj }\end{array}$ \\
\hline
\end{tabular}

\section{Interdisciplinary Spatial Planning Teams and Topics Covered}

As mentioned earlier, the main goal of this paper is to determine the need for interdisciplinary planning of national parks. Therefore, the status of spatial planning was analysed regarding only one category of protection, national parks. Today national parks are the most visited protected areas, and in addition, they have a large spatial extent, which is why they present a true challenge for spatial planners.

Analysis of spatial plans for areas with special features for the national parks in the Republic of Croatia gave an overview of the practice of spatial planning of protected nature destinations in Croatia. Also interviews were conducted with experts in the field of spatial planning that have contributed to making the final ratings, but also gave new perspectives on the possibilities of planning and management of protected areas, as well as the importance of an interdisciplinary approach to spatial planning.

Interdisciplinary planning is an important component of modern spatial planning that allows a systematic treatment of all elements, and emphasizes the professions that need to be involved in the planning: geography, architecture, construction, geodesy, biology, and forestry (Magaš, 2010).

\section{Interview-Current State and Implications}

To get a better insight in the practice of spatial planning in Croatia, eight interviews were conducted with 
experts in spatial planning of nature protected areas, who have participated in preparation and/or implementation of spatial plans. Questions were based on all protected areas spatial plans, with emphasis on national parks plans.

Planning experts have evaluated North Velebit plan, Plitvice lakes plan and plan of NP Mljet as the best spatial plans, while on the other hand, Kornati and Risnjak were pointed out as the plans with the most gaps. In the existing spatial plans of protected natural areas experts have singled out several weaknesses:

(1) Exaggerated technicistic and designed to serve the interests of users of spatial resources, rather than as an integrated plan for sustainable development of protected natural area;

(2) Poorly differentiated zoning for such specific areas for special purposes, as are the categories of ecosystem protection, and without social valuation of certain parts of space;

(3) Given the sensitive environment, or the delicate ecological balance, the zoning of protected natural areas should be largely based on the principle geo-ecological evaluation, taking into account the capacity and burden of all parts of complex geospatial areas;

(4) Some protected areas still have very old spatial plans in force, and these areas and the characteristics of the areas have changed considerably. Amendment and adoption of new plans do not track time or permanent and extensive changes in laws and regulations related to spatial planning.

On the other hand, as positive segments of current spatial plans experts have pointed out that they are trying to reconcile interests of nature protection regimes and social evaluation of resources, and also protect the public interest from profit-oriented stakeholders. Furthermore, they provide a legislative basis rectification of unacceptable interventions in space.

All experts think that the interdisciplinary planning team can improve the quality of spatial plans in development and implementation in practice, primarily due to the consideration of space from multiple aspects and integration of knowledge. Also, it was pointed out that interdisciplinary approach in spatial planning contributes to a fuller understanding of the specifics of each complex geospatial protected natural area, and thus and legality of their ecological systems. This is a prerequisite for the formation of an effective regime of protection of ecosystems and standardizing the appropriate (most appropriate) mode and extent of the valuation of certain parts of protected areas. Given the complexity of the planning of protected areas, especially national parks, according to experts, in spatial plan development of national parks appropriate experts from the fields of natural, social, technical, and interdisciplinary areas of science would certainly need to be involved. The exceptional importance of including experts from field of architecture, biology, hydrology, geography, geology, tourism, sociology, heritage conservation, ethnology, forestry, agronomy, law, chemistry, economy, and transport were emphasized, with the most important roles being natural sciences, tourism, and law. Spatial planning in Croatia in the transition period was characterized by the disappearance of interdisciplinary, on account of exclusivity and dominance of certain professions in planning teams (in the technical sciences, primarily - architecture), with a consequent lack understanding of the rules of development of ecosystems. Given that the goal of the design and development of spatial plans of protected natural areas is effective protection regime of ecosystems, it is evident that it is necessary to involve experts from the fields of natural (geology, biology, ecology, etc.) and interdisciplinary sciences (geography) in the planners' teams for making such plans. Spatial planners also emphasized the lack of experts from sociology, as well as from tourism, which should ensure "liveliness" of plans. 


\section{Spatial Plan Analysis}

Through analysis of the state of planning teams in the spatial plans, numerous weaknesses have been established.

For the purpose of this analysis, all members of the spatial planning process were singled out and it was established that the preparation of previous plans included as many as 20 fields, but depending on the spatial plan, the number of experts involved varied greatly. So it was established that the most interdisciplinary team was involved in the development of the Plitvice Lakes National Park spatial plan, with 52 experts from 16 fields. On the other hand, in the development of spatial plans during the 1990s, seven scientific disciplines were involved (NP Paklenica and Risnjak) (see Table 3). In the process, the very development of the plan had limited possibilities of viewing space through various creative approaches of individual sciences.

From the analysis of spatial plans, it is evident that from the rest of sciences in planning are in larger number participating experts from the field of biology, which is necessary given the very nature of the protection, wherein particular significance have ecologists and specialists such as, ornithologists, ichthyologists, mamologist, botanists, and others. As for the other sciences slightly higher incidence of involvement in planning teams have the geography, geology, and electro-technical sciences. On the other side, humanities and social sciences are minimally represented, which is an indicator of neglect of cultural and social values of the planned area.

Table 3

Number of Involved Professionals From Different Fields of Science

\begin{tabular}{|c|c|c|c|c|c|c|c|}
\hline Science/Field & Sjeverni Velebit & Risnjak & Brijuni & Plitvička jezera & Paklenica & Kornati & Mljet \\
\hline Architecture & 12 & 3 & 13 & 9 & 4 & 3 & 10 \\
\hline Geography & 2 & & 1 & 4 & 2 & & \\
\hline Civil engineering & 5 & 3 & 7 & 4 & 1 & & 4 \\
\hline Biology & 8 & 2 & 8 & 14 & 1 & & \\
\hline Geology & 1 & 1 & & 3 & 1 & & 3 \\
\hline Geodesy & 1 & 1 & & 2 & & & 1 \\
\hline Forestry & 3 & & 2 & 3 & 1 & & \\
\hline Archaeology & 1 & & 4 & 1 & & & \\
\hline History of art & 1 & & 1 & 2 & & & \\
\hline Agronomy & 1 & & & 4 & & & \\
\hline Transport & 2 & & & 1 & & & 2 \\
\hline Mechanical engineering & 2 & 1 & 3 & & & & \\
\hline Economy & & 1 & 1 & 1 & & & \\
\hline Electrical engineering & 1 & 2 & 5 & & 1 & & 2 \\
\hline Horticulture & & & & 1 & & & 1 \\
\hline Ethnology & & & & 1 & & & \\
\hline Animal health & & & 1 & & & & \\
\hline Mathematics & 1 & & & & & & \\
\hline Law & 1 & & & 1 & & & 4 \\
\hline Unknown & 6 & & & 1 & & & 4 \\
\hline Total & 48 & 14 & 46 & 52 & 11 & & 31 \\
\hline
\end{tabular}

Note. Sources: Ministry of Environment and Physical Planning (1999; 2000; 2001a; 2001b; 2003; 2010; 2011).

Among the 20 professions and sciences represented in the spatial plans, there are five from the technical field, seven natural sciences, two social sciences, three humanities, and one interdisciplinary science. In the 
technical field, the most common is the architectural experts, as well as town planning experts, whose main development goal is spatial design, where the creativity of each educated architect becomes an important factor. It is logical, therefore, that the largest number of experts involved come from this particular field, having in mind the fact they make almost half of the overall number of experts in individual plans. Construction is significantly represented as well, while other professions are represented to a far lesser extent. From the analysis of spatial plans, it is evident that from the rest of sciences in planning are in larger number participating experts from the field of biology, which is necessary given the very nature of the protection, wherein particular significance have ecologists and specialists such as, ornithologists, ichthyologists, mamologist, botanists, and others. As for the other sciences, slightly higher incidence of involvement in planning teams has the geography, geology, and electro-technical sciences. On the other side, humanities and social sciences are minimally represented, which is an indicator of neglect of cultural and social values of the planned area.

Also, there are no spatial plans for some national parks, while those already made are not completely coordinated, first and foremost due to the aforementioned time disproportion in planning. Therefore, it is necessary to determine some common guidelines for the future spatial plans. Modern, active environmental protection spreads to wider integrated areas and in that way the partial, dotted protection of specific attractions is less common, giving way to the protection of all levels of spatial design in general (Vidaković, 1997). According to this, it is necessary to approach the protection of national parks and other protected natural heritage objects not only through their spatial plans, but also through the spatial plans of administrative units which have to be included in the active protection processes based on their spatial planning documents.

The spatial dimension of sustainability involves numerous processes and links among different purposes of lands, ecosystems, and biotopes at different levels through time (Botequilha Leitão \& Ahern, 2002). Because of that, it is necessary to include all sciences and professions, whose common goal is the sustainability of the area, in the spatial planning process. It is also necessary to emphasize that geography has been frequently left out from the modern planning process and that it needs to be established among spatial planners, because interdisciplinarity is the key factor for good-quality spatial planning in general (Magaš, 2010), especially in the protected areas. As an interdisciplinary science in itself, geography should be in the future function as a bridge between natural and social sciences in the spatial planning of protected nature destinations.

\section{Conclusions}

Protected natural areas, especially national parks, present the most valuable areas of national territory and exceptionally attractive tourist destinations everywhere in the world, as well as in Croatia. Therefore, these areas have to be planned accordingly, with a special standard and care, respecting all the postulates of modern spatial planning. Since Croatia's independence, six of eight national parks have had a proposed spatial plan, while all are still being revised, whereas one is yet to be initiated. From a general point of view, the condition of national parks in Croatia is satisfactory. However, such condition cannot be self-sustained and that it is up to users and responsible individuals to think of the methods to preserve such a condition, as well as improve it as much as possible. Spatial planning imposes itself as the first and the most important method of active protection. It provides the necessary course of development which is the result of restrictions necessary for the purpose of planned development.

The spatial plan alone is not sufficient for the protection. Management plans coordinated with the spatial 
plans need to be made and everything has to be based on the carrying capacity and the indicators. If such plans are not constantly revised, they may cease to be "active" and become empty words, which is not in harmony with the current condition of an area. Therefore, it is necessary to: Set up interdisciplinary teams that will strive for the sustainability of protected nature destinations with the integration of knowledge; determine the capacity for broader and narrower areas; determine the indicators as critical points of the system and include the local community in a common mission to sustain the area.

\section{References}

Berke, P., Spurlock, D., \& Band, L. (2013). Local comprehensive plan quality regional ecosystem protection: The case of the Jordan lake watershed, North Carolina, U.S.A. Land Use Policy, 31, 450-459.

Botequilha Leitão, A., \& Ahern, J. (2002). Applying landscape ecological concepts and metrics in sustainable landscape planning. Landscape and Urban Planning, 59(1), 65-93.

Brown, G., \& Weber, D. (2011). Public participation GIS: A new method for national park planning. Landscape and Urban Planning, 102(1), 1-15.

Elliot, C., \& Udovč, A. (2005). Nature conservation and spatial planning in Slovenia, continuity in transition. Land Use Policy, 22(3), 265-276.

Fagence, M. (1990). Geographically-referenced planning, strategies to resolve potential conflict between environmental values and commercial interests in tourism development in environmentally sensitive areas. Journal of Environmental Management, $31(1), 1-18$.

Geneletti, D., \& Duren, I. (2008). Protected area zoning for conservation and use: A combination of spatial multicriteria and multiobjective evaluation. Landscape and Urban Planning, 85(2), 97-110.

Haslauer, E., Biberacher, M., \& Blasche, T. (2012). GIS-Based backcasting: An innovative method for parameterisation of sustainable spatial planning and resource management. Futures, 44(4), 292-302.

Hu, Y., Roo, G., \& Lu, B. (2013). "Communicative turn” in Chinese spatial planning? Exploring possibilities in Chinese context. Cities, 35, 42-50.

Institute for Tourism. (2006). Tomas nacionalni parkovi i parkovi prirode 2006-Stavovi i potrošnja posjetitelja nacionalnih parkova i parkova prirode u Hrvatskoj (Tomas national parks and nature parks 2006-Attitudes and consumption of visitors to national parks and nature parks in Croatia). Zagreb: Institute for Tourism.

Johnson, M. F., Kanderiana, N., Shanka, C. C., Rahmani, H., \& Lawsona, D. (2012). Setting priorities for protected area planning in a conflict zone-Afghanistan's national protected area system plan. Biological Conservation, 148(1), 146-155.

Liu, W. H., Wu, C. H., Jhan, H. T., \& Ho, C. H. (2011). The role of local government in marine spatial planning and management in Taiwan. Marine Policy, 35(2), 105-115.

Magaš, D. (2010). Applied geography in spatial planning. In I. Nejašmić (Ed.), International scientific conference "applied geography in theory and practice". Zagreb: University of Zagreb.

Marinović-Uzelac, A. (2001). Prostorno planiranje (Spatial planning). Zagreb: Dom i svijet.

Martinić, I. (2010). Upravljanje zaštićenim područjima prirode (Planiranje, razvoj i održivost) [Management of protected areas (Planning, development and sustainability)]. Zagreb: University of Zagreb, Faculty of Forestry.

McKenzie, F., Johnsona, M. F., Kanderiana, N., Shanka, C. C., Rahmani, H., Lawson, D., \& Smallwood, P. (2012). Setting priorities for protected area planning in a conflict zone-Afghanistan's National Protected Area System Plan. Biological Conservation, 148(1), 146-155.

McLaughin, J. B. (1969). Urban and regional planning - A system approach. London: Faber \& Faber.

Ministry of Environment and Physical Planning. (1999). Prostorni plan područja posebnih obilježja Nacionalni park "Paklenica" (Spatial plan of specific characteristics the National Park "Paklenica"). Zadar: Ministry of Environment and Physical Planning.

Ministry of Environment and Physical Planning. (2000). Prostorni plan područja posebnih obilježja Nacionalni park "Mljet" (Spatial plan of specific characteristics the National Park "Mljet”). Dubrovnik: Ministry of Environment and Physical Planning.

Ministry of Environment and Physical Planning. (2001a). Prostorni plan Nacionalnog parka "Brijuni" (Spatial plan of the National Park “Brijuni”). Zagreb: Ministry of Environment and Physical Planning. 
Ministry of Environment and Physical Planning. (2001b). Prostorni plan Nacionalnog parka "Risnjak" (Spatial plan of National Park "Risnjak"). Risnjak: Ministry of Environment and Physical Planning.

Ministry of Environment and Physical Planning. (2003). Prostorni plan područja posebnih obilježja Nacionalni park "Kornati" (Spatial plan of specific characteristics the National Park "Kornati"). Šibenik: Ministry of Environment and Physical Planning.

Ministry of Environment and Physical Planning. (2010). Prostorni plan područja posebnih obilježja Nacionalni park "Plitvička jezera", prijedlog za javnu raspravu (Spatial plan of specific characteristics the National Park "Plitvice Lakes", a proposal for a public debate). Zagreb: Ministry of Environment and Physical Planning.

Ministry of Environment and Physical Planning. (2011). Prostorni plan Nacionalnog parka "Sjeverni Velebit", nacrt konačnog prijedloga plana (Spatial plan of the National Park "Northern Velebit", the final draft of the plan). Zagreb-Gospić: Ministry of Environment and Physical Planning.

Narodne Novine. (2008). Nature Protection Act. Narodne Novine dd, 139(2), 1886-1941.

Narodne Novine. (2013). Nature Protection Act. Narodne Novine dd, 80(1), 1256-1286.

Plasman, C. (2008). Implementing marine spatial planning: A policy perspective. Marine Policy, 32, 811-815.

Pueyo-Anchuela, Ó., Casas-Sainz, A. M., Pocoví Juan, \& Ansón-López, A. D. (2011). Multidisciplinary approach for urban planning in alluvial karstic zones: Case study from the Central Ebro Basin (Spain). Engineering Geology, 122, 222-238.

Shafer, C. L. (1999). National park and reserve planning to protect biological diversity: Some basic elements. Landscape and Urban Planning, 44, 123-153.

Vidaković, P. (1997). Nacionalni parkovi u svijetu (priroda-kultura-turizam) [National parks in the world (nature-culture-tourism)]. Zagreb: Fund for Scholarships of Youth for Nature Protection and Tourism. 